This item was submitted to Loughborough's Research Repository by the author.

Items in Figshare are protected by copyright, with all rights reserved, unless otherwise indicated.

\title{
Bioleaching of copper via iron oxidation from chalcopyrite at elevated temperatures
}

PLEASE CITE THE PUBLISHED VERSION

PUBLISHER

Elsevier / ( ) The Institution of Chemical Engineers

VERSION

AM (Accepted Manuscript)

LICENCE

CC BY-NC-ND 4.0

\section{REPOSITORY RECORD}

Karimi, G. Reza, Neil A. Rowson, and Christopher J. Hewitt. 2010. "Bioleaching of Copper via Iron Oxidation from Chalcopyrite at Elevated Temperatures". figshare. https://hdl.handle.net/2134/6080. 
This item was submitted to Loughborough's Institutional Repository (https://dspace.lboro.ac.uk/) by the author and is made available under the following Creative Commons Licence conditions.

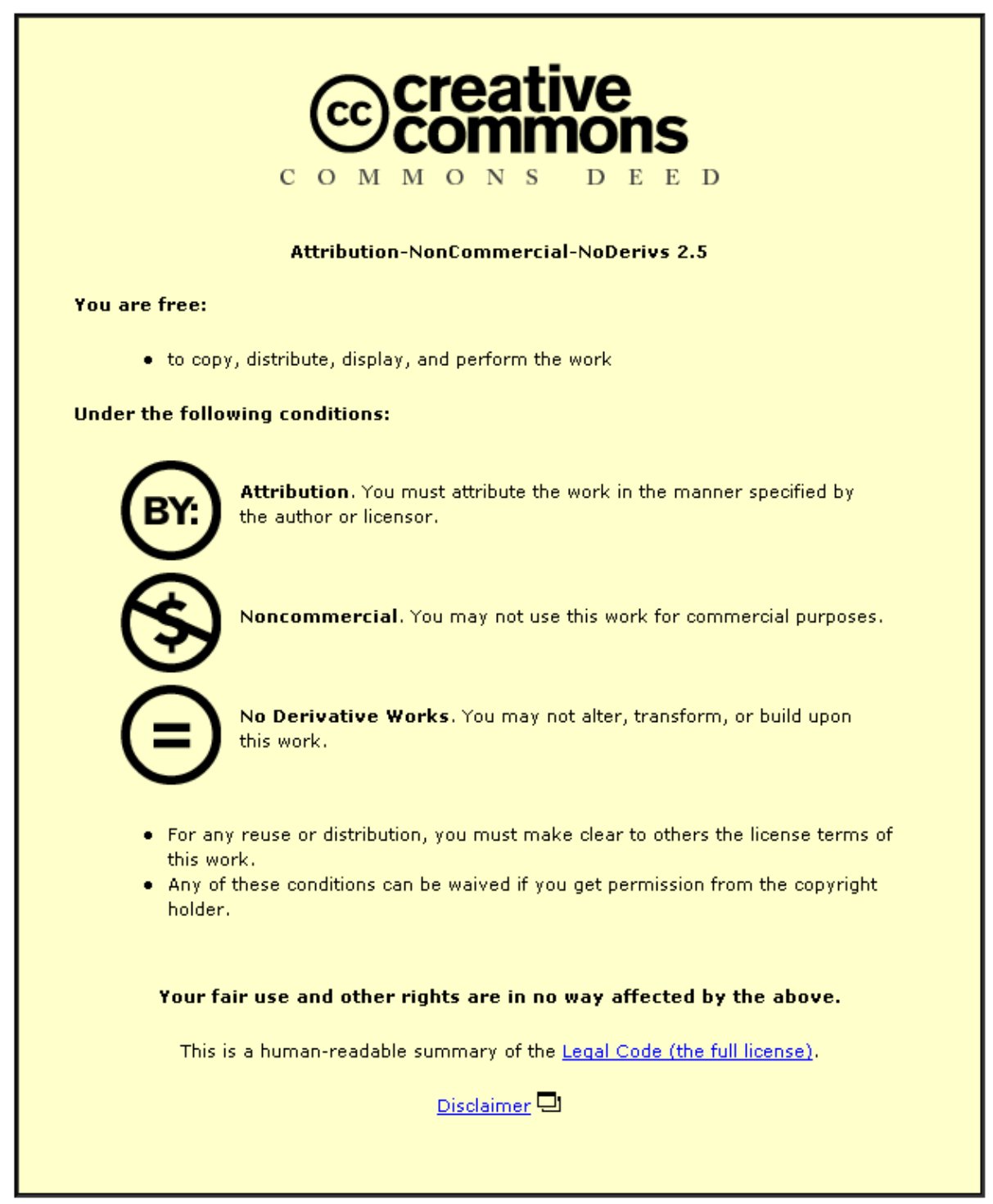

For the full text of this licence, please go to: http://creativecommons.org/licenses/by-nc-nd/2.5/ 


\title{
Bioleaching of copper via iron oxidation from chalcopyrite at elevated temperatures
}

\author{
G. Reza Karimi, Neil A. Rowson and Christopher J. Hewitt ${ }^{*}$ \\ ${ }^{1}$ Centre for Formulation Engineering, School of Chemical Engineering, The \\ University of Birmingham, Edgbaston, B15 2TT, UK. \\ ${ }^{2}$ Centre for Biological Engineering, Department of Chemical Engineering, \\ Loughborough University, Leicestershire, LE11 3TU, UK.
}

*Author for correspondence (Fax: +44 01509 222923; E-mail: c.j.hewitt@lboro.ac.uk.)

Keywords: Acidithiobacillus ferrooxidans, bioleaching, chalcopyrite, microbial catalysis

\begin{abstract}
The effect of elevated temperature on the bioleaching of copper from chalcopyrite, $\left(\mathrm{CuFeS}_{2}\right)$ via iron oxidation using Acidithiobacillus ferrooxidans under mesophilic conditions was studied. It was shown that temperature tolerant and ore adapted strains of At. ferrooxidans could extract copper significantly better than non-adapted cultures at elevated temperatures. The presence of soluble iron and its oxidative state, as a determining factor in copper leaching were found to be closely related to $\mathrm{pH}$ and temperature.
\end{abstract}




\section{INTRODUCTION}

Recently, there has been much interest in the development of biohydrometallurgical methods for the extraction of copper from sulphide minerals because they have many advantages over the more traditional pyrometallurgical techniques, including reduced emissions to air, simplicity of operation, low cost and applicability to low-value ores or mineral resources that can not be treated by conventional mining techniques ,Hsu and Harrison, 1995; Bosecker, 1997; Krebs et al., 1997). Amongst the metal sulphides that are oxidised by acidophilic bacteria, chalcopyrite $\left(\mathrm{CuFeS}_{2}\right)$ has deserved special attention since it is the most abundant copper-bearing mineral worldwide and also the principal mineral source from which copper is recovered commercially (Devi et al., 2000; Bevilaqua et al., 2004). The bioleaching of chalcopyrite at low temperatures $\left(<35^{\circ} \mathrm{C}\right)$ is usually done with one of a group of mesophilic bacteria usually either Acidithiobacillus ferrooxidans or Leptospirillum ferrooxidans because they can oxidise iron at a high rate, exhibit rapid growth and are able to tolerate high solid densities and iron concentrations. At. ferrooxidans (Kelly and Wood, 2000) is a wellknown iron and sulphur oxidizing bacterium and its role in the mining industry has been extensively reviewed (Torma, 1977; Lundgren and Silver, 1980; Ingledew, 1982; Imaizumi, 1986; Shiratori and Sonta, 1993; Rawlings, 1997). This organism oxidizes ferrous $\left(\mathrm{Fe}^{2+}\right)$ iron to ferric $\left(\mathrm{Fe}^{3+}\right)$ iron under acidic aerobic conditions to obtain energy for its growth. The latter can serve as an oxidant for the dissolution of sulphide minerals in bio-oxidation tanks or bioleaching heaps. Therefore the extraction of copper from chalcopyrite using micro-organisms is a combination of highly complex indirect chemical and biochemical leaching (by bacterial attachment) that occur simultaneously at the solid/liquid interface. This makes the understanding of solution chemistry more complicated and the role of key variables such as $\mathrm{pH}$, 
temperature and ferric concentration more difficult to quantify and interpret. Further the role and relative significance of the direct and indirect leaching mechanisms on mineral sulphide ores are not very well understood. Indeed, the mesophilic bioleaching of chalcopyrite is currently very slow and inefficient for a number of reasons. The chemical and microbial breakdown of chalcopyrite is basically ineffective at low temperatures because of the formation of diffusion barriers on mineral surfaces that slow down copper bio-extraction (Karimi et al., 2004; Rodreguez et al., 2003). However, some evidence suggests that at elevated temperatures the precipitation of iron as insoluble Jarosite $\left(\mathrm{XFe}_{3}\left(\mathrm{SO}_{4}\right)_{2}(\mathrm{OH})_{6}\right)$, which is thought to function as a biomass carrier, further enhances bacterial iron oxidation (Kinnunen and Puhakka, 2003). So the ability to increase the temperature of the process to improve bioleaching efficiency is important for the large scale effective treatment of refractory copper sulphides because it may prevent the formation of a diffusion barrier or passive layer on the mineral surface (Gericke et al., 2001; Petersen and Dixon, 2002; Third et al., 2000). Therefore in this work we compare the ability of temperature tolerant and ore adapted strains of At. ferrooxidans with nonadapted strains of At. ferrooxidans to operate efficiently at conditions out of their normal optimum range.

\section{METHODS AND MATERIALS}

\section{Bacterial strain and culture conditions}

Acidithiobacillus ferrooxidans (ATCC 19859) was used to inoculate the growth medium/chalcopyrite suspension or the growth medium (GM) where appropriate. Inoculum $\left(\sim 1.7 \times 10^{7}\right.$ cells $\left./ \mathrm{ml}\right)$ was produced on the GM and maintained at $4{ }^{\circ} \mathrm{C}$. GM is made up from two solutions. Solution A, $0.4 \mathrm{~g}\left(\mathrm{NH}_{4}\right)_{2} \mathrm{SO}_{4}, 0.2 \mathrm{~g} \mathrm{KH}_{2} \mathrm{PO}_{4}$ and 0.08 
g $\mathrm{MgSO}_{4} \cdot 7 \mathrm{H}_{2} \mathrm{O}$ made up in $400 \mathrm{ml}$ distilled water. Solution B, $10.0 \mathrm{~g} \mathrm{FeSO} \cdot \cdot 7 \mathrm{H}_{2} \mathrm{O}$ made up in $100 \mathrm{ml}$ distilled water and acidified with $1 \mathrm{ml} 0.5 \mathrm{M} \mathrm{H}_{2} \mathrm{SO}_{4}$. Solution A was autoclaved at $121{ }^{\circ} \mathrm{C}$ for 20 min whilst Solution B was filter-sterilised $(0.2 \mu \mathrm{m})$ and the two combined aseptically. The chalcopyrite $\left(\mathrm{CuFeS}_{2}\right)$ concentrate was obtained from Palabora mine South Africa (Rio Tinto, Bristol, England). It was ground with a ball mill and the size fraction of $106-150 \mu \mathrm{m}$ containing $28.2 \% \mathrm{w} / \mathrm{w}$ copper and $26.3 \% \mathrm{w} / \mathrm{w}$ iron was used for all leaching experiments. The starting $\mathrm{pH}$ of the GM was 2.8 .

\section{Temperature adaptation experiments}

Adaptation of At. ferrooxidans (ATCC 19859) to grow at higher temperatures $\left(35^{\circ} \mathrm{C}\right.$, $38{ }^{\circ} \mathrm{C}, 40{ }^{\circ} \mathrm{C}$ and $42{ }^{\circ} \mathrm{C}$ ) was done by sequentially sub-culturing in $50 \mathrm{ml}$ GM per 500 $\mathrm{ml}$ shake flask shaken at $100 \mathrm{rpm}$ and the required temperature. Since iron oxidation rate is proportional to bacterial growth, iron oxidation (ferrous to ferric) curves were used to follow the adaptation process. The culture was considered to be adapted when the time for complete ferrous oxidation was comparable to that achievable at $30{ }^{\circ} \mathrm{C}$ and the experiment terminated. The adapted strain from the immediately preceding temperature study was always used as the starting point for the next adaptation experiments at a higher temperature. Iron oxidation rate for each successive subculture was compared to that achievable from a non-adapted strain at $30{ }^{\circ} \mathrm{C}$.

\section{Adaptation to grow on chalcopyrite}

Adaptation of At. ferrooxidans (ATCC 19859) to grow on chalcopyrite as the sole iron source was done by sequentially sub-culturing in $50 \mathrm{ml}$ GM made up without $\mathrm{FeSO}_{4} \cdot 7 \mathrm{H}_{2} \mathrm{O}$ but supplemented with $5 \% \mathrm{w} / \mathrm{v}$ chalcopyrite in $500 \mathrm{ml}$ shake flasks 
shaken at $100 \mathrm{rpm}$ and $30{ }^{\circ} \mathrm{C}$. The adapted strain from the immediately preceding adaptation study was always used as the starting point for the next adaptation experiment. Control flasks were also set up as above but without inoculation with At. ferrooxidans.

\section{Analytical techniques}

For all experiments, $10 \mathrm{ml}$ samples were taken and filtered through a $0.45 \mu \mathrm{m}$ cellulose acetate membrane filter to remove precipitates and then acidified with $1.5 \mu \mathrm{l}$ concentrated $\mathrm{HNO}_{3}$ per $1 \mathrm{ml}$ sample. This was kept at $4{ }^{\circ} \mathrm{C}$ for total iron and copper content analysis using a Model 751 atomic absorption spectrophotometer (Instrumentation Laboratory, USA). The remainder of the sample was used to measure temperature, $\mathrm{pH}$ and in all cases reduction-oxidation (redox) potential using a Water Test Meter (Hannah Instruments, UK) calibrated as per the manufacturers instructions. Manual cell counts were done using a phase-contrast microscope and a Thoma counting chamber (depth, $0.02 \mathrm{~mm}$ ) from suitably diluted samples such that the total number of cells/ml could be back calculated. For ferrous iron concentration analysis $10 \mathrm{ml}$ Spekker acid $(375 \mathrm{ml}$ concentrated sulphuric and phosphoric acid made up to 11 with distilled water) was added to $5 \mathrm{ml}$ of culture sample. This was titrated against standard potassium dichromate, using sodium diphenyl sulphonate as an indicator, such that the concentration of ferrous iron $\mathrm{g} / \mathrm{l}$ is equal to the volume of potassium dichromate titrated.

\section{RESULTS AND DISCUSSION}

A series of experiments was carried out in $500 \mathrm{ml}$ shake flasks to investigate the iron oxidation capability of At. ferrooxidans at a range of temperatures using $\mathrm{FeS}_{4}$ or 
chalcopyrite as the sole iron source. Reproducible measurements of $\mathrm{pH}$, redox potential $(\mathrm{mV})$, total iron in solution $\mathrm{mg} / \mathrm{l}$, total copper in solution $\mathrm{mg} / \mathrm{l}$, total ferrous iron in solution and number of cells/ml were made for duplicate experiments (not all data shown, Figures $1-6)$.

\section{Effect of higher temperature on iron oxidation}

The ability of a mesophilic (unadapted) strain of At. ferrooxidans to oxidise iron where $\mathrm{FeSO}_{4}$ was the sole iron source was examined at a range of temperatures (35 ${ }^{\circ} \mathrm{C}, 38{ }^{\circ} \mathrm{C}, 40{ }^{\circ} \mathrm{C}$ and $\left.42{ }^{\circ} \mathrm{C}\right)$ higher than that usually considered to be optimal $\left(30{ }^{\circ} \mathrm{C}\right.$, Figure 1). The time required for a complete oxidation of $\mathrm{Fe}^{2+}$ was $36 \mathrm{~h}$ at $30^{\circ} \mathrm{C}$ and this was found to increase with temperature. However, oxidation of $\mathrm{Fe}^{2+}$ at $42{ }^{\circ} \mathrm{C}$ never reached completion presumably because microbial activity was hindered at this temperature. Approximately $5 \%$ of $\mathrm{Fe}^{2+}$ was oxidised after 120 hours in the control experiment without the addition of At. ferrooxidans. When At. ferrooxidans was consecutively sub-cultured on the GM using $\mathrm{FeSO}_{4}$ as the sole $\mathrm{Fe}^{2+}$ source at $30^{\circ} \mathrm{C}$, $35^{\circ} \mathrm{C}, 38^{\circ} \mathrm{C}$ and $40{ }^{\circ} \mathrm{C}$ the time required for complete iron oxidation after each subculture was substantially reduced (Figure 2 and 3, not all data shown). As temperature increased iron oxidation was more sensitive to temperature such that more subcultures were required at the higher temperatures to achieve complete $\mathrm{Fe}^{2+}$ oxidation in a comparable time to that achieved at $30{ }^{\circ} \mathrm{C}$. Such adapted cultures were used in subsequent bioleaching experiments.

\section{Effect of elevated temperatures on bioleaching with At. ferrooxidans.}

The effectiveness of an unadapted At. ferrooxidans culture for copper and iron dissolution (bioleaching) from chalcopyrite at $30{ }^{\circ} \mathrm{C}$ and $40{ }^{\circ} \mathrm{C}$ were compared (Figure 
4a). Both copper and iron dissolution capability was reduced at $40{ }^{\circ} \mathrm{C}$ when compared to that at $30{ }^{\circ} \mathrm{C}$, but this reduction was much more pronounced for copper than for iron. Indeed copper extraction reduced from $21.4 \%$ at $30{ }^{\circ} \mathrm{C}$ to $5.9 \%$ at $40{ }^{\circ} \mathrm{C}$ over a 26 day period indicating very poor bacterial performance at $40^{\circ} \mathrm{C}$. Iron dissolution at $30{ }^{\circ} \mathrm{C}$ was slightly higher than that at $40{ }^{\circ} \mathrm{C}$ however, the amount of iron released to the solution was higher than copper $(\mathrm{Cu} / \mathrm{Fe}<1)$ at $40{ }^{\circ} \mathrm{C}$. Not unsurprisingly, the ability to oxidise $\mathrm{Fe}^{2+}$ and release $\mathrm{Cu}$ from the chalcopyrite is related to bacterial growth and metabolic activity (Figure 4b) since microbial growth was inhibited and hence redox potential low at $40{ }^{\circ} \mathrm{C}$. This suggests that a sub-culture of At. ferrooxidans adapted to iron oxidation and growth at higher temperatures could be used for the bioloeaching of chalcopyrite at elevated temperatures.

\section{Effect of temperature adaptation on the bioleaching of chalcopyrite.}

A sub-culture of At. ferrooxidans that had previously been adapted to $\mathrm{Fe}^{2+}$ oxidation at $40{ }^{\circ} \mathrm{C}$ was used for copper and iron dissolution (bioleaching) from chalcopyrite at $40{ }^{\circ} \mathrm{C}$ and its performance compared with that of an unadapted culture (Figure 5). Both copper and iron were dissolved at a higher rate for the adapted sub-culture when compared to that of the unadapted culture. In contrast to the results at $30^{\circ} \mathrm{C}$, both adapted and unadapted strains released iron faster than copper at $40{ }^{\circ} \mathrm{C}$ (i.e. $\mathrm{Cu} / \mathrm{Fe}<1$ ). The temperature tolerant bacteria could extract $22.6 \%$ of the copper over a 32 -day period with concomitant iron dissolution of $23.8 \%$. For the adapted sub-culture both copper and iron dissolution are comparable to that achievable at $30{ }^{\circ} \mathrm{C}$ with the unadapted strain this is at odds with the theory that the use of an elevated temperature should enhance chalcopyrite bioleaching. The addition of $4 \mathrm{~g} / 1 \mathrm{Fe}^{3+}$ to the GM supplemented with chalcopyrite was found to enhance the initial bacterially mediated 
copper dissolution rate with an unadapted strain of At. ferrooxidans at $30^{\circ} \mathrm{C}$ and a temperature adapted strain at $40{ }^{\circ} \mathrm{C}$ (Table 1) and that bioleaching then proceeds more efficiently especially at the elevated temperature. It is believed that the association between high redox potential in mesophilic $\left(30{ }^{\circ} \mathrm{C}\right)$ bioleaching and the apparent decline in copper dissolution rate could be cause and effect. It is known that At. ferrooxidans can oxidise ferrous iron more rapidly than some other bacteria which causes an increase in the $\mathrm{Fe}^{3+} / \mathrm{Fe}^{2+}$ ratio in solution however the indirect chemical cause of the bioleaching based on the chemical interaction of free ferric ions with the chalcopyrite is hindered at low temperatures and ferric iron builds up in solution (Karimi et al., 2004). The oxidation of ferrous to ferric iron results in a higher $\mathrm{pH}$ which in turn reduces ferric iron solubility and hence its effect on the chalcopyrite (Gomez and Cantero, 1998; Mazuelos et al., 2001; Rodreguez et al., 2001). This can cause a significant precipitation of iron hydroxide (partly as a layer at the mineral surface) where regenerated ferrous iron is produced (Kinzler et al., 2003; Tributsch, 2001). Microenvironments at the mineral surfaces with a high local $\mathrm{pH}$ allow precipitation to continue even though the bulk $\mathrm{pH}$ might decrease due to the formation of iron hydroxides later. This could be connected to the high redox potential that is experienced in the bioleaching of chalcopyrite by mesophilic bacteria and could be due to the fact that after the formation of an iron hydroxide diffusion barrier or passive layer indirect chemical leaching is inhibited. This keeps the ferric/ferrous ratio high even at lower concentrations of total iron.

\section{Bioleaching with a culture adapted to grow on chalcopyrite}

It is generally accepted that any changes to the physical or chemical environment of a bacterial cell can result in a negative effect on metabolism. This can be minimised by 
adapting the bacteria to the new conditions. This is particularly so when laboratory strains of bacteria are exposed to natural environments. In the laboratory, cultures of At. ferrooxidans are grown on well defined media and an ideal physical environment ( $\mathrm{pH}$, Temperature) is maintained therefore changing the source of iron from $\mathrm{FeSO}_{4}$ to chalcopyrite is highly likely to have a negative effect on bacterial function, which will result in a slower leaching process. Therefore the effect of bacterial adaptation to growth on chalcopyrite on any subsequent bioleaching efficiency was studied. Bioleaching experiments were carried out on the GM supplemented with chalcopyrite as the sole iron source using unadapted and adapted cultures of At. ferrooxidans after 0, 2 and 4 weeks adaptation (Figure 6 not all data shown). It was found that copper extraction increased considerably with adapted bacteria whilst iron dissolution decreased with adaptation time. Hence the total $\mathrm{Cu} / \mathrm{Fe}$ ratio in solution increased significantly with length of adaptation. There is no clear explanation as to whether the total iron in solution is mainly controlled by iron dissolution rate or by factors affecting iron solubility during the bioleaching of chalcopyrite. However, the findings of this work suggest that the solubility of the products is controlled by factors such as temperature, $\mathrm{pH}$ and redox potential all of which have major roles in determining the $\mathrm{Cu} / \mathrm{Fe}$ ratio.

\section{CONCLUSIONS}

It was shown that temperature tolerant and ore adapted strains of At. ferrooxidans could extract copper from chalcopyrite significantly better than non-adapted cultures at elevated temperatures. The presence of soluble iron and its oxidative state was found to be closely related to $\mathrm{pH}$ and temperature (with regards to the mesophilic conditions) and to be a determining factor in copper leaching kinetics. It is suggested 
that at higher temperatures the indirect chemical leaching of copper from chalcopyrite or contact leaching, where bacteria concentrate ferric ions close to the mineral surface (Sand et al., 2001), dominates the leaching system. The role of adapting bacteria to grow on chalcopyrite was shown to be decisive in promoting bioleaching efficiency and demonstrates the potential of using such a system for the recovery of copper from chalcopyrite ore, which has a high ferrous iron content.

\section{ACKNOWLEDGEMENT}

This study was supported by grants from the Iranian Ministry of Science, Research and Technology.

\section{REFERENCES}

Bevilaqua D., Diez-Perez I., Fugivara C.S., Sanz F., Benedetti A.V. and Garcia O., 2004 Oxidative dissolution of chalcopyrite by Acidithiobacillus ferrooxidans analyzed by electrochemical impedance spectroscopy and atomic force microscopy. Bioelectrochemistry. 64: 79-84.

Bosecker K., 1997 Bioleaching: metal solubilisation by microorganisms. FEMS Microbiol. Rev. 20: 591-604.

Devi N.B., Madhuchhanda M., Srinivasa R.K., Rath P.C. and Paramguru R.K. 2000 Oxidation of chalcopyrite in the presence of manganese dioxide in hydrochloric medium. Hydrometallurgy. 57: 57-76.

Gericke M., Pinches A. and Van Rooyen, J.V., 2001 Bioleaching of a chalcopyrite concentrate using an extremely thermophilic culture. Int. J. Miner. Process. 62: $243-255$. 
Gómez J.M. and Cantero D., 1998 Modelling of ferrous sulphate oxidation by Thiobacillus ferroxidans in discontinuous culture: influence of temperature, pH and agitation rate. J. Ferment. Bioeng. 86: 79-83.

Hsu C.H. and Harrison R.G., 1995 Bacterial leach of zinc and copper from mining wastes. Hydrometallurgy. 37: 169-179.

Imaizumi T., 1986 Some industrial applications of inorganic microbial oxidation in Japan. Biotechnol. Bioeng. 16: 363-371.

Ingledew W.J., 1982 Thiobacillus ferrooxidans; The bioenergetics of an acidophilic chemolithotroph. Biochim. Biophys. Acta. 683: 89-1 17

Karimi G.R., Hewitt C.J. and Rowson N.A., 2004 Chemical and bacteria aspects of bioprocessing of chalcopyrite. Cell. Mol. Biol. Lett. 9 :28-29.

Kelly D.P. and Wood A.P., 2000 Reclassification of some species of Thiobacillus ferrooxidans to the newly designated genera Acidithiobacillus Halothiobacillus and Thermithiobacillus. Int. J. Syst. Bacteriol. 50: 511-516.

Kinnunen P.H-M. and Puhakka J.A., 2003 High rate ferric sulfate generation by a Leptospirillum ferriphilum-dominated biofilm and the role of Jarosite in biomass retainment in a fluidised-bed reactor. Biotechnol. Bioeng. 85: 697705.

Kinzler K., Gehrke T., Telegdi J. and Sand W., 2003 Bioleaching - a result of interfacial processes caused by extracellular polymeric substances (EPS). Hydrometallurgy. 71: 83-88.

Krebs W., Brombacher C., Bosshard P.P., Bachofen R. and Brandl H., 1997 Microbial recovery of metals from solids. FEMS Microbiol. Rev. 20: 605-617.

Lundgren D.G. and Silver M., 1980 Ore leaching by bacteria. Annu. Rev. Microbial. 34: 263-283. 
Mazuelos A., Palencia I., Romero R., Rodriguez G. and Carranza F., 2001 Ferric iron production in packed bed reactors: Influence of $\mathrm{pH}$, temperature, particle size, bacterial support and type of air distributor. Miner. Eng. 14: 507-514.

Petersen J. and Dixon D.G., 2002 Thermophilic heap leaching of a chalcopyrite concentrate. Miner. Eng. 15: 777-785.

Rawlings D.E., 1997 Mesophilic, autotrophic bioleaching bacteria: description, physiology and role. In: Rawlings DE ed. Biomining. Berlin: Springer pp 229245.

Rodreguez Y., Ballester A., Blazquez M.L., Gonzalez F. and Munoz J.A., 2003 New information on the chalcopyrite bioleaching mechanism at low and high temperature. Hydrometallurgy. 71: 47-56.

Sand W., Gehrke T., Jozsa P.G. and Schippers A., 2001 Biochemistry of bacterial leaching-direct vs indirect bioleaching. Hydrometallurgy. 59: 159-175.

Shiratori T. and Sonta H., 1993 Application of iron-oxidizing bacteria to hydrometallurgical flue dust treatment and $\mathrm{H}, \mathrm{S}$ desulfurization. FEMS Microbiol. Rev. 11: 165-174.

Third K.A., Cord-Ruwisch R. and Watling H.R., 2000 The role of iron-oxidizing bacteria in stimulation or inhibition of chalcopyrite bioleaching. Hydrometallurgy. 57: 225-233.

Torma A.E., 1977 The roll of Thiobacillus ferrooxidans in hydro-metallurgical processes. Adv. Biochem. Eng. 6: 1-37.

Tributsch H., 2001 Direct versus indirect bioleaching. Hydrometallurgy. 59: 177-185. 
Table 1. Effect of initial ferric iron concentration on bioleaching rates of chalcopyrite at $30{ }^{\circ} \mathrm{C}$ and $40{ }^{\circ} \mathrm{C}$ with temperature adapted and mesophilic cultures of At. ferrooxidans.

Figure 1. Iron oxidation for mesophilic cultures of At. ferrooxidans at temperatures 30 ${ }^{\circ} \mathrm{C}(\quad), 35^{\circ} \mathrm{C}(\mathbf{\bullet}), 38^{\circ} \mathrm{C}(\Delta), 40^{\circ} \mathrm{C}(\mathrm{x}), 42{ }^{\circ} \mathrm{C}(\square)$ and control at $40^{\circ} \mathrm{C}(\mathrm{O})$.

Figure 2. Iron oxidation for successive sub-cultures of At. ferrooxidans on GM with $\mathrm{FeSO}_{4}$ as the sole iron source at $30{ }^{\circ} \mathrm{C}$.

Figure 3. Iron oxidation for successive sub-cultures of At. ferrooxidans on GM with $\mathrm{FeSO}_{4}$ as the sole iron source at $40{ }^{\circ} \mathrm{C}$.

Figure 4a) Bioleaching of chalcopyrite with mesophilic At. ferrooxidans at $30{ }^{\circ} \mathrm{C}$ and $40{ }^{\circ} \mathrm{C}$; $\mathrm{Cu}$ extraction at $30^{\circ} \mathrm{C}(\boldsymbol{\Delta})$ and $40{ }^{\circ} \mathrm{C}(\Delta)$; Fe dissolution at $30^{\circ} \mathrm{C}(\boldsymbol{\square})$ and $40{ }^{\circ} \mathrm{C}$ (口). b) Cell number $/ \mathrm{ml}$ at $30{ }^{\circ} \mathrm{C}(\boldsymbol{\square})$ and $40{ }^{\circ} \mathrm{C}(\bullet)$; redox potential $(\mathrm{mV})$ at $30{ }^{\circ} \mathrm{C}(\square)$ and $40{ }^{\circ} \mathrm{C}(\mathrm{o})$.

Figure 5. The effect of temperature adaptation on chalcopyrite bioleaching with At. ferrooxidans at $40{ }^{\circ} \mathrm{C}$; $\mathrm{Cu}$ extraction with the adapted (•) and mesophilic (o) strain, $\mathrm{Fe}$ dissolution with the adapted ( $\square)$ and mesophilic strain $(\square)$.

Figure 6. Bioleaching of chalcopyrite with and without 4 weeks adaptation chalcopyrite ore as the sole source of iron; unadapted $\mathrm{Cu}$ extraction $(\Delta)$, unadapted $\mathrm{Fe}$ dissolution ( $\square$ ), adapted $\mathrm{Cu}$ extraction $(\boldsymbol{\Delta})$ and adapted Fe dissolution $(\boldsymbol{\square})$ at $30^{\circ} \mathrm{C}$. 
